Zrinka Božić Blanuša

University of Zagreb

zbblanus@ffzg.hr

ORCID: 0000-0002-6438-6542
Data przesłania tekstu do redakcji: 11.11.2019

Data przyjęcia tekstu do druku: 28.01.2020

\title{
Decentred Geographies: Poetics and Politics of the Avant-garde*
}

Abstract: Božić Blanuša Zrinka, Decentred Geographies: Poetics and Politics of the Avant-garde. "Poznańskie Studia Slawistyczne" 18. Poznań 2020. Publishing House of the Poznań Society for the Advancement of the Arts and Sciences, Adam Mickiewicz University, pp. 49-66. ISSN 2084-3011.

Thanks to the work of Pascale Casanova, Franco Moretti, David Damrosch and many others, over the past two decades, the concept of world literature has once again become the subject of thorough examination within the field of literary studies, especially in relation to cosmopolitanism and globalization. When it comes to the study of individual national literatures and specific regional contexts, as well as to the definition of comparative literature as a discipline, debates regarding its background, its reach and limitations could not be ignored. World literature thus appears as a heterogenous entity - always manifesting in different contexts in different forms - consistently in dialogical exchange with specificities of a particular literature and culture.

Instead of discussing the problematic relation between centre and periphery or criticizing the idea of global literary and cultural canon, the avant-garde as an international and global phenomenon that appears even more radically on the so-called periphery is what is of primary interest to me. Therefore, the purpose of this paper is to demonstrate that avant-garde (in its various forms and radical expressions) simultaneously challenges art as an institution and introduces the idea of a decentred geography of world literature.

KEYwORDS: world literature; centres; peripheries; progress; simultaneity

Speaking to his friend and secretary, Johann Paul Eckermann, in 1827, Johann Wolfgang Goethe coined the term world literature (Weltliteratur). Nevertheless, until the late 1990s and early 2000s, it was used mainly to describe a distinct field of study; without any critical reflection, it was understood simply to refer to "world literature in contrast to national literature" and indicated "little interest in the methodological consequences of the

* This work has been supported in part by the Croatian Science Foundation, under the project Literary Revolutions IP-2018-01-7020. 
subject" (Rosendahl Thomsen, 2008, 15). According to David Damrosch (2003b, 1), "the term crystallized both a literary perspective and a new cultural awareness, a sense of an arising global modernity, whose epoch [...] we now inhabit." However, the term, Damrosch admits, was from its very inception elusive: "What does it really mean to speak of a "world literature'? Which literature, whose world?" Indeed, Goethe never attempted to provide a coherent definition of the term. Beside famous conversations with Eckermann, it has mainly appeared in his subsequently published letters, aphorisms and diary entries. ${ }^{1}$ Rosendahl Thomsen $(2008,11-12)$ has interpreted Goethe's proclamation that "the epoch of world literature is at hand, and everyone must strive to hasten its approach" to be an expression of his "longing for a larger context that takes his authorship out of its German confines and into a sphere that needed to be defined in order to be discovered, and to see the writer's work not as borrowing from other literature, but as belonging to it." World literature, Damrosch $(2003 \mathrm{~b}, 5)$ insists, "is not an infinite, ungraspable canon of works" and "it is not at all fated to disintegrate into the conflicting multiplicity of separate national traditions." One has to agree with Franco Moretti $(2000,55)$ when he claims that world literature "cannot be literature, bigger; what we are already doing, just more of it." Rather, it is a distinct concept that requires completely different categories. In addition, he explains:

I will borrow this initial hypothesis from the world-system school of economic history, for which international capitalism is a system that is simultaneously one and unequal: with a core, and a periphery (and a semi periphery) that are bound together in a relationship of growing inequality. One, and unequal: one literature (Weltiteratur, singular, as inter-related literatures); but a system which is different from what Goethe and Marx had hoped for, because it's profoundly unequal (Moretti, 2000, 55).

${ }^{1}$ Referring to the period of almost ten years between the introduction of the term in 1927 and the publication of Gespräche mit Goethe in 1936, Pizer (2012, 3) explains: "because in 1827 the suppression of nationalist sentiments in the German states resulting from the decrees of the 1815 Congress of Vienna was still quite effective, while by 1836 such sentiments were flaming anew and efforts to stamp them out were becoming increasingly futile. The political atmosphere created by repressive ancien regime policies in 1820 s Germany and in Europe as a whole. It is important to keep this circumstance in mind in order to understand both the most significant principles Goethe intended to convey with this term, and its seminal importance for present-day debates on literary globalization." 
For him, "one and unequal" means that the fate of a peripheral culture depends on the dynamics of a larger, more influential "culture (from the core) that completely ignores it" (Moretti, 2000, 55; follow Even-Zohar, 1990, 54-62). Speaking about peripheries within the context of world literature, one has to keep in mind that the binary core/periphery (or centre/periphery) concept was applied in the 1960s by scholars (political economists and sociologists) who "challenged dominant views of development as synonymous with economic growth" (Petrusewicz, 2019, 17). As Petrusewicz $(2019,18)$ explains: "The full implications of the 'core'/ 'periphery' relationship can only be observed in an integrated world economy, integration that started with the onset of the modern world-system and reached its apex in the late nineteenth century." ${ }^{2}$ On the other hand, Terlouw $(2003,71)$ argues that the introduction of the concept of semi periphery was a step forward in the analysis of global inequalities: "An extra category does more justice to the complex spatial inequalities than a simple core-periphery dichotomy." This is why the concept of semi periphery, as category characterized by its specific in-betweenness, has been introduced by Immanuel Wallerstein: "'Looking at the world economy as a whole, some states are clearly 'in-between' in the core-periphery structure, in that they house within their borders [...] both peripheral processes in relation to core states and core-like processes in relation to adjacent peripheral states" (Hopkins according to Klobucka, 1997, 121). It is not a descriptive category, but "an analytical instrument to study change" (Terlouw, 2003, 71-72) and it "improves the understanding of the changing spatial organization within the world-system." In her influential study, The World Republic of Letters (La République mondiale des Lettres), Pascale Casanova, referring to Fernand Braudel (1992), describes the established literary map of Europe as a consequence of "the unequal structure [...] of

${ }^{2}$ Petrusewicz $(2019,18)$ continues: "Only then, in parallel with the new imperialism, was the dogmatic view of development as a unique progressive process consolidated. Until then, across the world, different paths of development were envisaged, and none of them yet perceived as inherently core or peripheral."

${ }^{3}$ The Modern World-System, vol. I: Capitalist Agriculture and the Origins of the European World-Economy in the Sixteenth Century (1974); vol. II: Mercantilism and the Consolidation of the European World-Economy, 1600-1750 (1980); vol. III: The Second Great Expansion of the Capitalist World-Economy, 1730-1840's (1989); vol. IV: Centrist Liberalism Triumphant, 1789-1914 (2011). 
literary space, the uneven distribution of resources among national literary spaces" (Casanova, 2004, 83). These spaces, thus, "slowly establish hierarchies and relations of dependency that over time create a complex and durable design" and consequently there emerges "a relatively unified space characterized by the opposition between the great national literary spaces, which are also the oldest [...] and those literary spaces that have more recently appeared and that are poor by comparison." According to Casanova, since the oldest literary spaces do not need any justification in national political space, they are the most autonomous and primarily devoted just to literature without any other purpose or goal. As she explains:

Literary space translates political and national issues into its own terms - aesthetic, formal, narrative, poetic - and at once affirms and denies them. Though it is not altogether free from political domination, literature has its own ways and means of asserting a measure of independence; of constituting itself as a distinct world in opposition to the nation and nationalism, a world in which external concerns appear only in refracted form, transformed and reinterpreted in literary terms and with literary instruments. In the most autonomous countries, then, literature cannot be reduced to political interests or used to suit national purposes. It is in these countries that the independent laws of literature are invented, and that the extraordinary and improbable construction of what may properly be referred to as autonomous international space of literature is carried out (Casanova, 2004, 86).

This process of emancipation from national context and national politics, Casanova claims, was crucial for Paris to become the literary capital of the world in the nineteenth century, gravitated to by writers from different parts of the world who aspired to artistic autonomy.

When Moretti, taking into account the problem of inequalities, argues for different categories in the study of world literature, he introduces the concept of distant reading, "where distance [...] is a condition of knowledge," that makes possible a focus on "units that are much smaller or much larger than the text: devices, themes, tropes - or genres and systems" (Moretti, 2000, 57). For him, the loss of meaning - even of the text itselfsustained in the attempt to grasp and understand the system in its entirety is not an unsurmountable problem. This is why Jonathan Arac (2002) criticizes the project of "Conjectures" as "Formalism without close-reading" (v. Moretti, 2013, 118), or why Damrosch (2003a, 518), with some concern, asks: "are students of world literature really going to have to leave 
the analysis of actual works to specialists in national literatures?" Moretti $(2013,118)$ admits to the partial adoption of formalism, but promises to highlight the details and not let them be erased by models and schemes. In his view, "the trouble with close reading (in all its incarnations, from the new criticism to deconstruction) is that it necessarily depends on an extremely small canon" (Moretti, 2000, 57). As Rosendahl Thomsen (2012, 141) further explains: "By looking narrowly and somewhat unsystematically, as most close readers do, they are bound to miss something in terms of contexts, the risks of presenting what was typical of the time as something unique, and a backdrop of small differences that can help to explain why certain works fare better than others in the international system and in literary history." This is why Moretti $(2000,57)$ argues that close reading cannot fulfil the task of transcending the canon: "It is not designed to do it, it's designed to do the opposite" In fact, he adds, "it is a theological exercise - very solemn treatment of very few texts taken very seriously whereas what we really need is a little pact with the devil: we know how to read texts, now let's learn how not to read them."

Any departure from the core/periphery or centre/periphery dichotomy of world literature presupposes some kind of literary geography: "an active force, that pervades the literary field and shapes it in depth" (Moretti, 1998, 3). Literary geography relies on maps and maps allow us to see relations and connections that would otherwise remain unnoticed. As an analytical tool "worth a thousand words," Moretti $(1998,3)$ explains, a map is able to "dissect the text in an unusual way," enabling us to appreciate a wider perspective. Even more importantly, mapping a literary phenomenon is just the beginning of geographical work which generates, according to Moretti $(1998,7)$, "the most challenging part of the whole enterprise: one looks at the map, and thinks." One thinks about relations, distances, influences, domination, resistance, different dynamics, various contexts, models, structures, systems, rules and exceptions.

Power relations within literary space are not permanent; inequalities within the system generate constant struggles and rebellions. Heroes of Casanova's account, according to Rosendahl Thomsen $(2008,18)$, "are writers who change the system from the periphery" while simultaneously remaining "dependent on the centres of the international literary space." In his view, she has introduced the concept the Greenwich Meridian of 
Literature as a "clever metaphor borrowed from synchronization of the clocks of the world, which run differently, but are all set by the same standard" (Rosendahl Thomsen, 2008, 17). So, if that is the case, if rebels are our heroes, what about the avant-garde? How are we to understand the almost simultaneous appearance of different avant-garde groups, each with their specific programmes, in various places, centres and peripheries, in completely different contexts? How can we explain their impact on the system of world literature or, to be more precise, how can we draw a geographical map of the avant-garde?

World literature, according to Rosendahl Thomsen $(2008,26)$, "is usually envisioned in spatial terms, but there are important temporal dimensions to world literature that affect the ways in which world literature can be comprehended." Therefore, world literature as a paradigm, as well as a field of study, requires an elaborate concept of temporality that will lead "to very different ideas of world literature, and present alternate conditions for research, criticism and teaching." By introducing temporality, instead of focusing exclusively on the Eurocentrism of world literature (in terms of core/periphery dichotomy), I propose to a certain extent different understanding of the geopolitical impact of various avant-gardes on the system of world literature. This means also that mapping the avant-garde would require considering its specific temporality. Indeed, the avant-garde has often been defined as a more radical and advanced form of modernism, characterized by its explicit political impulse. This may be partially attributed to the etymology of the term: " "Originally a military word, used to designate the advance corps of an army," it is a name of a small group whose members conceived themselves as being "advanced" in relation to the majority of their contemporaries, one step closer to a utopia that lay in

${ }^{4}$ According to Szabolcsi $(1971,49)$ : “Originally it was used in a military sense and the first journal so named is a military one from the period of the French Revolution, launched in 1794. As a political term it seems to appear around 1830 in Republican circles and among the opposition of the monarchy in general. It becomes more popular in Utopian Socialist terminology; the Saint-Simonite Emile Barrault is probably the first who uses it in 1830, then around 1845 it appears in the works of G. D. Laverdant, disciple of Fourier, and about the same time Proudhon's writings, too, already as a label for social progress, for socialist ideas and the collective efforts of artists. By the second half of the century the 'avant-garde' becomes part of the stock phraseology of politics; in France between 1880 and 1910 countless newspapers, periodicals and publications bear it as a title, and its novelty is worn off in political slang." 
the future but whose realization was already under way" (Puchner, 2005, 77). This means that there is an intrinsic understanding of temporality embedded in the concept of avant-garde. Accordingly, it departs from the idea that there is, as Puchner $(2005,77)$ writes, "a unified historical axis along which humanity moves, some being ahead and some being behind, the axis of progress that would soon be internalized by the manifesto." This intrinsic temporality of the avant-garde is, in fact, an expression of, what Reinhart Koselleck - in his influential study Futures Past: On the Semantics of Historical Time (Vergangene Zukunft. Zur Semantik geschichtlicher Zeiten, 1979) - defines as a specific experience of historical time (geschichtliche Zeit), "a concept that emerged during the eighteenth century and gave rise to several new historical concepts, including progress" (Doorman, 2003, 22). In Koselleck's view, the gradual disintegration that resulted in a definitive rejection of Christian apocalyptic thought was a crucial change in the prevailing experience of history. In other words, "While doubts arose about the day of Judgement as the end of worldly history, a linear sense of time with an open future began to gain ground" (Doorman, 2003, 22 ). With the advent of these new attitudes concerning the future, time lost its static character: "acceleration and deceleration, and with them the possibility of influencing more global historical processes, could now be conceived of" (Doorman, 2003, 22). This is what enabled the new idea of progress and acceleration: once understood in eschatological terms, it gradually became "a call for an earthly future" (Doorman, 2003, 22), a goal that could actually be achieved. This belief was an important part of the new experience of historical time. In Doorman's opinion, Koselleck's concept of contemporaneity of the noncontemporaneous (Gleichzeitigkeit der Ungleichzeitigen), was an important aspect of this new conceptualization of temporality: "The dynamic of similar developments taking place in different tempos, that is, of non-contemporaneous developments taking place in the same period" (Doorman, 2003, 23). For Koselleck (2004, 95), contemporaneity of the noncontemporaneous ${ }^{5}$ is one of three modes of temporal experience (beside irreversibility of events and repeatability of

\footnotetext{
${ }^{5}$ According to Koselleck $(2004,95)$ : “A differential classification of historical sequences is contained in the same naturalistic chronology. Within this temporal refraction is contained a diversity of temporal strata which are of varying duration, according to the agents or circumstances in question, and which are to be measured against each other."
} 
events) and one of the three formal criteria from which, when combined, "it is possible to deduce conceptually progress, decadence, acceleration, or delay." As "a result of overseas expansion," it gradually "became a basic framework for the progressive construction of a world history increasingly unified since eighteenth century" (Koselleck, 2004, 246). In fact, the term progress (in the form of a collective singular) was introduced "opening up all domains of life with questions of 'earlier than,' or 'later than,' not just 'before' and 'after'" (Koselleck, 2004, 246). The self-perception of being ahead of one's time has been expressed by the Encyclopaedists (in relation to the unenlightened and uneducated masses), by Friedrich Schlegel (who was concerned about different levels of intellectual and moral development), Kant (discussing the discrepancy between civilization and morality) and - in the most dramatic way - by the avant-garde.

This means that the concept of progress and avant-garde are closely connected, even inseparable. One possible explanation of this relation and an interesting insight to avant-garde's contribution to art history has been provided by Peter Bürger. His Theory of the Avant-garde (Theorie der Avantgarde, 1974) was the first major study of this movement, defining the avant-garde "with regard to certain changes in the perception of the social functions of art" (Murphy, 2004, 5). According to John Roberts $(2015,1)$, "the avant-garde in its revolutionary forms produced a profound shift in expectations about art that coincided with the demise of traditional bourgeois modes of aesthetic judgement." Referring to Kant's notion of the aesthetic (as a position between sensuousness and reason) and his definition of taste (as free and disinterested), Bürger $(1984,46)$ emphasizes:

the autonomy of art is a category of bourgeois society. It permits the description of art's detachment from the context of practical life as a historical development - that among the members of those classes which, at least at times, are free from the pressures of the need for survival, a sensuousness could evolve that was not part of any mean-ends relationships.

[...] this detachment of art from practical contexts is a historical process, i.e., that it is socially conditioned.

[...] The relative dissociation of the work of art from the praxis of life in bourgeois society thus becomes transformed into the (erroneous) idea that the work of art is totally independent of society. In the strict meaning of the term, 'autonomy' is thus an ideological category that joins an element of truth (the apartness of art from the praxis of life) and an element of untruth (the hypostatization of this fact, which is a result of historical development as the 'essence' of art). 
So, in other words, avant-garde is (and this is Bürger's major contribution) challenging the status - and the prevailing understanding of the function - of art in bourgeois society; it is not an attack on earlier styles or previous forms, it is not an expression of a demand to make art practical once again and it is not a departure from the content of individual works. Aestheticism, as Bürger reminds us, is characterized by a definite distance from the praxis of everyday life and based on a pragmatic means-ends rationality. The aim of the avant-garde is not "to integrate art into this praxis.” In Bürger's (1984, 49-50) words, the avant-gardists:

assent to the aestheticists' rejection of the world and its means-ends rationality. What distinguishes them from the latter is the attempt to organize a new life praxis from a basis in art.

$[\ldots]$

Only an art the contents of whose individual works is wholly distinct from the (bad) praxis of the existing society can be the centre that can be the starting point for the organization of a new life praxis.

In view of that, one has to agree with Roberts' $(2015,18)$ position that Bürger "reclaims the cultural, political and cognitive specificity of the avant-garde as separate from modernism as such." In his attempt to redefine avant-garde (in its latter manifestations) as still capable of addressing the problem of the status of art (even though the circumstances have changed), Roberts - regarding the dialectics of autonomy (following Adorno) - argues: "in order to resist the pressures of abstract labour, art must find ways and means of being in the world and not of the world [...] and therefore must find ways and means of being both 'social fact' and 'asocial"' (Roberts, 2015, 34).

Moreover, the range of expressions of avant-garde radicality are rooted not only in its positioning within the social context. For instance, Bürger $(1984,17)$ claims that "the connection between the insight into the general validity of a category and the actual historical development of the field to which this category pertains [...] also applies to the objectifications in the arts." For him, "artistic means" is the most general category that can be used to classify different works of art. However, thanks to the so-called historical avant-garde, various techniques and procedures have been recognized as belonging to "artistic means." Previously, the use of "artistic means" has been limited and prescribed by the period style. So if Viktor 
Shklovsky, according to Bürger, regards defamiliarization (or estrangement) as an artistic technique, "recognition that this category is a general one is made possible by the circumstance that in the historical avant-garde movements, shocking the recipient becomes the dominant principle of artistic intent" (Bürger, 1984, 18). In other words, by becoming the dominant artistic technique, defamiliarization can be established as a general category. The consequences and effects of such reconceptualization of artistic practice and reception (proposed by Shklovsky) are, for Bürger, far-reaching and crucial, not only in defining theoretical premises of the avant-garde, but also in changing (in fact, inverting) the temporal perspective of art history and (possibly) literary history:

It is my thesis that certain general categories of the work of art were first made recognizable in their generality by the avant-garde, that it is consequently from the standpoint of the avant-garde that the preceding phases in the development of art as a phenomenon in bourgeois society can be understood, and that it is an error to proceed inversely, by approaching the avant-garde via the earlier phases of art (Bürger, 1984, 19).

However, this still does not explain the idea of decentred geographies of the avant-garde proposed by the title of this essay. According to Béatrice Joyeux-Prunel, the canonical account of art history has been derived "from a naïve idea of World history, made of three main presuppositions that are the core of the modernist tale: the first, that art history is a linear continuation of progress; the second, that innovation happens in one 'centre' that decides what time it is - a Greenwich meridian of modernity; and lastly, that the peripheries of this centre remain deemed to imitation, borrowing, or influence" (Joyeux-Prunel, 2015, 41). This canonical narrative, she explains, is "based on the assumption that history was guided by a principle of progress and systematic negation, and that this progression took place in one single location" (Joyeux-Prunel, 2018, 1). This does not only mean that the centre-periphery dichotomy defines the concept of modernity, but also that such a conceptualization of art (and literary) history, beside introducing "aesthetics as monoliths," completely "omits avant-gardes born in remote areas"(Joyeux-Prunel, 2018, 2). ${ }^{6}$ As Joyeux-Prunel reminds us,

${ }^{6}$ In addition, Joyeux-Prunel $(2018,2)$ explains: "It also justifies the international domination of a small Parisian elite who are seen as the model of cultural, ethical, and political progress in the history of modern art and culture. [...] Finally, the idea of Parisian centrality 
"the recognition and institutionalisation of Modernism was closely tied with a collective endeavour" of social, artistic and intellectual elites "to gain centrality," as indeed was the case everywhere: in Europe, the United States, Latin America, the Middle East and Asia (Joyeux-Prunel, 2015, 45). In her view, around 1900, the centre of modernity was not represented by a single city, such as Paris, but in fact constituted "a social network," an exclusive group, a special class of rich cosmopolitan collectors "who could afford to travel" and visit numerous exhibitions and Salons. ${ }^{7}$ Every artist who wanted to be internationally recognized, Joyeux-Prunel (2015, 49) explains, "had to closely follow this pattern." It is therefore completely understandable that the impetus for the international reaction against this system sprang from the revolt of "young artists from socially lower strata, who didn't pass the 'social exam' required to enter the networks of modern art." The appearance of various avant-gardes in different parts of Europe were all a reaction against the "hegemony of an internationally marketed modern art that was dominated and produced by and for socially cosmopolitan elite that they could not even imagine reaching." According to Joyeux-Prunel $(2015,49)$, the explosion of avant-gardes "that were for the most part anti-elitist, anti-cosmopolitan, and locally oriented, is a structural historical fact all over Europe around 1905-1908 and cannot be reduced to the shallow explanation of Parisian influence."

However, adopting Bourdieu's concept of social field, Joyeux-Prunel argues that, in terms of the historical account of the avant-garde, this field has been structured by mobility. In her opinion, it has always been an

in the history of modernism before 1940 is a prerequisite for the idea that New York 'stole' modernism from Paris after the 1940s - an interpretation of the global history of art that relies almost exclusively on sources from New York. According to this assumption, Europe invented nothing new after the 1940s. Neither did anywhere else, in particular the eastern side of the Iron Curtain and Latin America, not to mention the African, Asian or Austral 'no man's land"'.

7 "Those collectors, such as the German Count Harry Kessler, could be in Brussels in February, in Paris in the spring, summer in Venice, and go to Berlin for the fall, then back to Paris again for the Salon d'Automne after 1903. The Modern Elite and their painters met also regularly in important places of leisure such as Venice, the Normandy coast, Baden-Baden in Germany, or the Côte d'Azur. They gathered in private salons located in the rich cosmopolitan areas of the main European capital cities, such as the Parisian Faubourg, or the Berlin Tiergarten. Everyone could speak French and English, meet celebrated modern artists, order one's portrait and visit elite exhibitions" (Joyeux-Prunel, 2015, 49). 
international field which is why by "focusing on the circulation of avant-garde-artists and their works, as well as the social, economic, financial, geopolitical, and colonial bases of these circulations, and on the cultural transfers and resemanticizations that took place in the circulation, we can understand how some groups, artists, stories, and centres managed to establish themselves better than others" (Joyeux-Prunel, 2018, 2). In her circulatory approach, Joyeux-Prunel $(2018,3)$ demonstrates how Paris in the 1920s isolated itself from the international avant-garde, "unlike Germany and Central Europe, which were more open." In fact, according to her, Paris became a global centre of avant-garde circulation only in the mid-1930s. Focusing on biographical data - analysing the references and preferences of the most important artistic figures of the period, examining their trajectories and offering an exhaustive and comprehensive cartography of the foundation of modernist and avant-garde journals in the 1920s - Joyeux-Prunel (2015) challenges the idea of centrality of Paris. Faced with a rather exclusive environment, she writes, foreign artists left Paris in order to find more open and suitable places in which to establish themselves. They "decided to go where artistic innovation was thriving" (Joyeux-Prunel, 2018, 6) - to Berlin, Weimar and Hanover: to Central and Eastern Europe:

Whereas Parisian market was focused on unique works and signatures, the new European cities formed an integrated chain of schools (such as Bauhaus and its Hungarian equivalent), workshops, and shops, which led to orders of architectural designs and decorations. The work was then collective. The aim was to pass on, serve, and make oneself understood.

In other words, the so-called peripheries were more open to revolutionary experiments - to innovations and challenges - than the artistic capital. Therefore, one has to agree with Joyeux-Prunel's definition of the inter-war European avant-garde as polycentric: "Whereas the avant-garde journals related to the Dadaist vogue were buried in Paris in 1922, they abounded in Cologne, Hanover, Zurich, and Berlin, and in Cracow, Munich, Vienna, Prague, and Zagreb" (Joyeux-Prunel, 2018, 6). In fact, the Parisian artistic circles "did not even seem to have the desire any longer to be avant-garde" (Joyeux-Prunel, 2018, 7). On the other hand, European avant-gardes were more and more aware that "they had to reclaim public 
space over one another" (Joyeux-Prunel, 2015, 50): this led to a special kind of rivalry, which is why, for instance, Futurists "openly used nationalist mottos, published their manifestos in many different places, and travelled all over Europe to organize thunderous performances and exhibitions" (Joyeux-Prunel, 2015, 50).

In my opinion, avant-garde in its various forms (artistic, literary, political) and radical expressions not only challenge the bourgeois understanding of the function of art but also introduce the idea of a decentred geography of world literature, thereby promoting polycentric understandings of literary and art history. Various groups advancing specific programmes have emerged simultaneously in centres and peripheries, or semi-peripheries, with the same radical demand to challenge the institution of art, to reject the ideologized concept of autonomy, in attempt to change the present. Let us recall the proclamation of Filippo Tommaso Marinetti $(2009,51)$ in the Manifesto of Futurism:

We stand on the last promontory of the centuries!... Why should we look back over our shoulders, when we intend to breach the mysterious doors of the Impossible? Time and Space died yesterday. We already live in the absolute, for we have already created velocity which is eternal and omnipresent.

It is precisely this omnipresence, polycentrism and simultaneity that defines the spatiotemporality of the avant-garde. Progressive movements all over Europe shared the same belief in the authority and power of art to change the world and to shape a new society. As Mansbach $(1990,7)$ has emphasized, the agenda was the same "whether the particular movement was Dutch, German, Italian, or French; and paradoxically, it was especially true for those artists and cultural movements that emerged on the eastern periphery of industrialized Europe, where 'modernity,' 'progressivism,' and 'development' existed more forcefully in imagination and desire that in social and material fact." It is as if, by being more radical in their demands, the progressivist artistic and literary movements on the peripheries were trying to compensate for the belatedness of modernization in their domestic contexts. According to Mansbach (1990, 7): "From their geographically peripheral standpoint - with the advantages and liabilities that distance affords - and with heightened awareness of their respective cultural traditions, the Central and Eastern European movements were in 
a unique position to contribute significantly to the development of modern art, aesthetics, and art history." In fact, by informing the Western artistic community of "the new visions being articulated on the eastern periphery of Europe, the small-circulation reviews and periodicals succeeded in integrating the signal contributions of the avant-garde of Eastern Europe into the mainstream of modern art." By casting aside the difference between centre and periphery - and introducing politics of simultaneity - the avant-garde was a unique movement in the geopolitical history of art (and literature): a true expression of democracy. ${ }^{8}$

Instead of a conclusion, this paper will end with an illustration from the so-called periphery. In the 1920 s, Zenit was the seminal avant-garde journal in the new Balkan state - the Kingdom of Serbs, Croats and Slovenes (later renamed as the Kingdom of Yugoslavia). Artistic and intellectual activity in this new state was concentrated in the former provincial centres of the Austro-Hungarian Empire (Ljubljana, Zagreb and Novi Sad), as well as in the new capital Belgrade. Zenit, initiated in 1921 by the poet and critic Ljubomir Micić, “was published until 1923 in Zagreb, then transferred to Belgrade for what was hoped to be a more sympathetic environment" (Subotić, 1990b, 21). ${ }^{9}$ For Micić, Zenit was a media for presenting and propagating the programme of Zenitism and a means "for establishing a direct link with international avant-garde artists, movements and magazines" (Šimičić, 2003, 298). Programmatically heterogeneous (combining Cubism, Futurism, and Expressionism), the international character of the

8 "Each in its own time, these movements and their leading personalities were well-known and remarkably well represented in the myriad of 'little reviews' that were published through-out Europe (and America). Thus, Die Aktion, De Stijl, L'Esprit Nouveau, Der Sturm, and Broom, to mention only few Western reviews, publicized the progressive poets and artists of Eastern and Central Europe; and the editors of Eastern European avant-garde publications - Ma (Budapest and Vienna), Disk and Pasmo (Prague), Contimporanul (Bucharest), and Zenit (Zagreb and Belgrade), among the most well-known - reciprocated by publishing and fostering an appreciation of Western advanced art among their own readers. The resultant cross-fertilization of the avant-garde was fully international and extended modern art's reach from Petrograd to Paris and well beyond" (Mansbach, 1990, 7).

${ }^{9}$ However, even in Belgrade, Subotić (1990a, 15) writes, "Micić encountered opposition to Zenit's alleged 'Bolshevik propaganda and [its] appeal to citizens to [foment] a socialist revolution.' After forty-three issues, the review was finally proscribed by the authorities in December 1926." Subotić refers to "Zenitizam kroz prizmu marksizma" in an article published in 1926 in Zenit by M. Rasinov, who was in fact, Subotić claims, Micić himself. 
periodical was achieved through collaboration with famous writers and visual artists (Marinetti, Mayakovsky, Blok, Esenin, Khlebnikov, Kandinsky, Malevich, Gropius, Kassák, etc.) and by publishing works of avant-garde poetry, prose and theatre as well as articles on the latest artistic and literary developments in their original languages (French, Russian, English, German, Hungarian, Flemish and even Esperanto).${ }^{10}$ Clearly, the purpose of Zenit, Irina Subotić (1990b, 21) claims, was to "articulate the cause for international modernism consistent with the perceived needs of indigenous Yugoslav culture." However, despite its anti-traditionalist stance, "Zenitism acknowledged indigenous roots, which it believed, could introduce fresh blood and awaken healthy, young, original and forceful tissue in a fatigued and war-exhausted European civilization" (Subotić, 1990a, 15). As Glisic and Vujosevic $(2016,719)$ explain, as a product of two major tendencies that shaped Yugoslav cultural space in the 1920s, the Balkanist discourse and European avant-garde rhetoric, Zenitism "saw itself as a unique contributor to the Yugoslav idea using the avant-garde language of irrelevance, iconoclasm and provocation to challenge the asymmetric East-West power dynamic and to subvert dominant stereotypes about Balkan-Slavic 'barbaric' Orient." Being simultaneously an ex First World War soldier and an avant-garde artist, Micić attempted to subvert the Eurocentric stance of intellectual, artistic, and political history: "In Zenitist texts this view would be expressed in a famous reversal of the ancient myth of the Rape of Europa, with Europe cast as the rapist in the guise of an old syphilitic whore preying upon the young Balkans" (Glisic, Vujosevic, 2016, 722). The imagined figure of Barbarogenius, an embodiment of "the primitive, young, ingenious, and dynamic spirit of the Balkans" has been introduced by Micić himself to oppose "the decrepit, morally bankrupt and creatively impotent European civilization” (Glisic, Vujosevic, 2016, 723). In fact, as Micić (1922) proclaimed in one of his programmatic texts, "the raw energy of the Balkans should be used 'to Balkanize Europe,' to instil new energy into its listless culture, and to reverse the traditional process

10 "[...] Zenit appeared on the international scene at the beginning of 1921 and quickly was included in the family of the most reputable avant-garde reviews of the time, such as Der Sturm, Het Overzicht, L'Esprit Nouveau, Ma, Blok, Devetsil, Vešč-Objet-Gegenstand, Contimporanul and 7 Arts" (Subotić, 1990a, 15). 
of 'Europeanizing the Balkans"” (Glisic, Vujosevic, 2016, 723). Glisic and Vujosevic conclude:

The Zenitist ‘Balkanization' of Europe was designed as an act through which Europe would come to mirror the Balkan Peninsula. By this process, the role of the Balkans as imitator of imposed European models would be replaced by European imitation of the Balkan ethos by transforming Europe into a fragmented continent and a cultural war zone in which a host of militant factions would fight for domination. Was it not Balkanization, thus defined, that was the very foundation of European avant-gardes? Micić did not have to go any further than to present the competing avant-garde movements on one platform to demonstrate the familiar patterns of the Balkan stereotype in the very midst of the Western avant-garde scene: both were rebellious, factional, and aggressive, as stereotypes would have it (Glisic, Vujosevic, 2016, 728).

The heterogeneity of the Zenitist project, visible in its editorial approach as well as in its programmatic diversity, is just one specific illustration of how the avant-garde works: it opens spaces, establishes relations, enables cacophony, disrupts domination, decentres maps and rearranges power relations.

As a unique movement in the history of world literature, one should not be surprised that generations have repeatedly (and maybe desperately) attempted to relive avant-garde (in the 1960s as neo-avant-garde in various parts of the world, in the 1980s as retro-avant-garde in Yugoslavia) simultaneously in the so-called centres and the so-called peripheries. Power relations within literary space are not permanent which is why, according to Pascale Casanova $(2004,175)$, "the only genuine history of literature is one that describes the revolts, assaults upon authority, manifestos, inventions of new forms of languages." The purpose of this text was to demonstrate that no one has the monopoly to radicality. This is why rethinking avant-garde in relation to world literature and world literature in relation to avant-garde requires taking three radical concepts - progress, simultaneity, and polycentrism into account.

\section{References}

Arac, J. (2002). Anglo-Globalism?. "New Left Review” vol. 2, no. 16.

Braudel, F. (1992). Civilization and Capitalism: 15th-18th Century: The Perspective of the World. Vol 3. Trans. S. Reynolds. Berkley: University of California Press. 
Bürger, P. (1984). Theory of the Avant-garde. Minneapolis: University of Minnesota Press.

Casanova, P. (2004). The World Republic of Letters. Cambridge Massachusetts: Harvard University Press.

Damrosch, D. (2003a). World Literature, National Contexts. "Modern Philology" vol. 100, no. 4, pp. 512-531. https://doi.org/10.1086/379981.

Damrosch, D. (2003b). What is World Literature? New Jersey: Princeton University Press. https://doi.org/10.1515/9780691188645.

Doorman, M. (2003). Art in Progress: A Philosophical Response to the End of the Avant-garde.Amsterdam:Amsterdam University Press. https://doi.org/10.5117/9789053565858.

Even-Zohar I. (1990). Laws of Literary Interference. "Poetics Today", pp. 54-62.

Glisic, I., Vujosevic, T. (2016). I am Barbarogenius: Yugoslav Zenitism of the 1920s and the Limits of Performativity. "Slavic and East European Journal" vol. 60, no. 4, pp. 718-743.

Joyeux-Prunel, B. (2015). Provincializing Paris. The Centre-Periphery Narrative of Modern Art in Light of Quantitative and Transnational Approaches. "Artl@s Bulletin" vol. 4, no. 1, pp. 40-64.

Joyeux-Prunel, B. (2018). Peripheral Circulations, Transient Centralities: The International Geography of the Avant-gardes in the Interwar Period (1918-1940). "Visual Resources". https://doi.org/10.1080/01973762.2018.1476013.

Klobucka, A. (1997). Theorizing the European Periphery. "Symploke" vol. 5, no. 1/2 pp. 119-135. https://doi.org/10.1353/sym.2005.0061.

Koselleck, R. (2004). Futures Past: On the Semantics of Historical Time. Trans. K. Tribe. New York: Columbia University Press.

Mansbach, S.A. (1990). From Leningrad to Ljubljana: The Supressed Avant-gardes of East-Central and Eastern Europe during the Early Twentieth Century. "Art Journal" vol. 49, no. 1, pp. 7-8. https://doi.org/10.2307/777174, https://doi.org/10.1080/ 00043249.1990 .10792661$.

Marinetti, F.T. (2009). The Founding and Manifesto of Futurism. In: Futurism: An Anthology. Eds L. Rainey, Ch. Poggi, L. Wittman, New Haven-London: Yale University Press.

Moretti, F. (1998). Atlas of the European Novel 1800-1900. London-New York: Verso.

Moretti, F. (2000). Conjectures on World Literature. "New Left Review" no 1, pp. 54-68.

Moretti, F. (2013). More Conjectures. Distant Reading. London-New York: Verso.

Murphy, R. (2004). Theorizing the Avant-garde: Modernism, Expressionism and the Problem of Postmodernity. Cambridge: Cambridge University Press.

Petrusewicz, M. (2019). Rethinking Centre and Periphery in Historical Analysis: Land-based Modernization as an Alternative Model from the Peripheries. In: Re-Mapping Centre and Periphery: Asymmetrical Encounters in European and Global Contexts. Eds T. Hauswedel, A. Körner, U. Tiedau, London: UCL Press. https:// doi.org/10.2307/j.ctv550cmg.4.

Pizer, J. (2012). Johann Wolfgang von Goethe: Origins and Relevance of Weltliteratur. 
In: The Routledge Companion to World Literature. Eds T. D'haen, D. Damrosch, D. Kadir. Routledge: London-New York.

Puchner,M.(2005).Poetryofthe Revolution: Marx, Manifestoes and the Avant-garde.Princeton-Oxford: Princeton University Press. https://doi.org/10.1515/9781400844128. Roberts, J. 2015, Revolutionary Time and the Avant-garde. London: Verso.

Rosendahl Thomsen, M. (2008). Mapping World Literature: International Canonization and Transnational Literatures. London-New York: Continuum.

Rosendahl Thomsen, M. (2012). Franco Moretti and the Global Wave of Novel. The Routledge Companion to World Literature. Eds. T. D’haen, D. Damrosch, D. Kadir. London-New York: Routledge.

Subotić, I. (1990a). Zenit and Zenitism. "The Journal of Decorative and Propaganda Arts" vol. 17, pp. 14-25. https://doi.org/10.2307/1504074.

Subotić, I. (1990b). Avant-garde Tendencies in Yugoslavia" "Art Journal" vol. 49, no. 1, special issue: From Leningrad to Ljubljana: The Supressed Avant-gardes of East-Central and Eastern Europe during the Early Twentieth Century, pp. 21-27. https://doi.org/10.2307/777174.

Szabolcsi, M. (1971). Avant-garde, Neo-avant-garde, Modernism: Questions and Suggestions. "New Literary History" vol. 3, no. 1, pp.49-70. https://doi.org/10.2307/ 468380.

Šimičić, D. (2003). From Zenit to Mental Space: Avant-garde, Neo-avant-garde, and Post-avant-garde: Magazines and Books in Yugoslavia, 1921-1987. In: Impossible Histories: Historical Avant-gardes, Neo-avant-gardes and Post-avant-gardes in Yugoslavia, 1981-1991. Eds D. Djurić, M. Šuvaković. Cambridge-London: MIT Press.

Terlouw, K. (2003). Semiperipheral Developments: From World-Systems to Regions. "Capitalism Nature Socialism" vol. 4, no. 14, pp. 71-90. https://doi.org/10.1080/ 10455750308565547. 